\title{
RELASI GENETIS BAHASA-BAHASA TIMOR
}

\section{GENETIC RELATION OF TIMOR LANGUAGE}

\author{
Halus Mandala \\ halusm@ymail.com \\ Tanggal naskah masuk: 10 Oktober 2012 \\ Tanggal revisi terakhir: 23 November 2012
}

\begin{abstract}
This research is focused on the study of seven languages in the island of Timor consisting of (1) Tokodede language, (2) mambae language, spoken by the people in the west part of Timor. (3). Kemak language, (4) Tetun, actually spoken by population in NTT but spread to Timor Leste, (5) Dawan language, (6) Rote language, and (7) Helong language, develop in NTT. It is hypothesized that those languages have genetic relationship though part of them are classified as non-Austronesia language (Capell, 1945). The data is collected by means of listed words of Swadesh and Holle, which are then analyzed by diacomparative method. Some accurate data are found to prove the genetic relation of such languages as the Timor group. Based on quantitative and qualitative evidences, the Timor language group consists of three sub-groups namely TKM, DTR, and HI which can be constructed in the form of genetic relation pedigree by dwipalah pattern. Phonological innovation unifying the Timor group includes apoke, sinkope, unifying sound, and forwarding the central sound of PAN * 2 . The evidences for phonological innovation which breaks the group are PT*b to PTKM*h, to PDTR*h, to PDTR*f, and to HI b. Moreover, there are evidences that show the breaking of the groups and unifying each sub-group as well. Then, It is found a phonological shared innovation of apokope and metaphysic in sub-group of DTR within the sub-group of TKM. A phonological shared innovation of metathesis and paragoge is found within the sub-group of HI. At last, Exclusivelly shared linguistic innovation is found for the PT lexical, PTKM sub-group lexical, PTDR sub-group lexical, and HI.
\end{abstract}

Keywords: genetic relation, language grouping, proto-language reconstruction, diacomparative

\begin{abstract}
Abstrak
Penelitian relasi bahasa ini mengkaji tujuh bahasa di Pulau Timor meliputi bahasa (1) Tokodede dan (2) Mambae ditutur masyarakat Timor Leste bagian barat, bahasa (3) Kemak dan (4) Tetun dipakai di NTT menyebar sampai ke wilayah Timor Leste, bahasa (5) Dawan, (6) Rote, dan (7) Helong berkembang di NTT. Semua bahasa itu dihipotesiskan mempunyai hubungan kekerabatan, meskipun sebagian bahasa-bahasa itu diklasifikasikan sebagai bahasa Non-Austronesia (AN) (Capell, 1945). Data dikumpulkan menggunakan daftar Swadesh dan Holle yang dianalisis dengan metode diakomparatif, diperoleh bukti akurat keeratan relasi genetis bahasa-bahasa itu sebagai kelompok bahasa Timor. Berdasarkan bukti kuantitatif dan kualitatif, kelompok bahasa Timor memiliki tiga subkelompok, yakni TKM, DTR, dan Hl yang dapat disusun dalam bentuk silsilah relasi genetis bahasa Timor dengan pola dwipilah. Inovasi fonologis penyatu kelompok Timor berupa apokope, sinkope, penunggalan bunyi, dan pengedepanan bunyi sentral PAN *d. Bukti inovasi fonologis pemisah kelompok berupa PT *b menjadi PTKM *h, PDTR *f, dan Hl b. Selain itu, ditemukan pula bukti pemisah kelompok sekaligus penyatu subkelompok masing-masing. Dalam subkelompok TKM ditemukan bukti inovasi fonologis bersama berupa apokope dan metatesis pada subkelompok DTR. Pada subkelompok $\mathrm{Hl}$ ditemukan pula bukti inovasi fonologis bersama berupa metatesis dan paragoge. Di samping itu ditemukan pula exclusively shared linguistic innovation yaitu inovasi leksikal bersama baik untuk leksikal PT, leksikal subkelompok PTKM, leksikal subkelompok PDTR dan leksikal Hl.
\end{abstract}

Kata kunci: relasi genetis, pengelompokan bahasa, rekonstruksi protobahasa, diakomparatif. 


\section{Pendahuluan}

Penelitian linguistik historis komparatif ini menjangkau tiga belas bahasa yang hidup dan berkembang di Pulau Timor. Bahasa-bahasa tersebut diduga memiliki hubungan kerabatan. Khusus bahasa-bahasa di Timor Leste dikategorikan menjadi dua kelompok, yakni kelompok bahasa Austronesia (AN) dan kelompok bahasa-bahasa Non-Austronesia $\quad(\mathrm{NAN})^{1}$. $\quad$ Blust $^{2}$ mengatakan bahasa-bahasa tersebut sebagai sebuah kelompok bahasa AN. Dyen $^{3}$ secara tegas juga menyatakan bahwa bahasa-bahasa di Pulau Timor merupakan subkelompok tersendiri sebagai bagian dari kelompok AmbonTimor sebagai bahasa AN. Hanya saja, Dyen tidak merinci jumlah dan namanama bahasa yang menjadi anggota subkelompok itu.

Dari tiga belas bahasa yang diteliti, terbukti tujuh bahasa yang memiliki relasi genetis, yakni bahasabahasa (1) Tokodede (Tk), (2) Kemak (Km), (3) Mambae (Mb), (4) Dawan (Dw), (5) Tetun (Tt), (6) Rote (Rt), dan (7) Helong ( $\mathrm{Hl})$. Ketujuh bahasa tersebut, secara geografis tersebar pada dua wilayah pakai, yakni wilayah Timor Leste dan wilayah Indonesia. Bahasa-bahasa $\mathrm{Tk}$ dan $\mathrm{Mb}$ digunakan oleh masyarakat di wilayah Timor Leste bagian Barat. Bahasa Tt dan Km hidup di Atambua Provinsi NTT wilayah Indonesia menyebar sampai ke wilayah Timor Leste bagian barat dan timur. Tiga bahasa lainnya, yakni Dw, $\mathrm{Rt}$, dan $\mathrm{Hl}$ ditutur oleh masyarakat di
Timor Tengah Utara, Timor Tengah Selatan, SoE, serta Kabupaten Kupang dan sekitarnya yang berada di Propinsi Nusa Tenggara Timur wilayah Indonesia.

Bahasa-bahasa tersebut sangat menarik untuk diteliti. Di samping karena adanya versi pengelompokan di atas, juga semua penelitian itu hanya bardasarkan pada metode by inspection dengan bukti kuantitatif dan tidak dilengkapi dengan bukti-bukti relasi genetis yang akurat yang bersifat kualitatif seperti disarankan Blust ${ }^{4}$. Penelitian terhadap sebagian bahasabahasa itu pernah dilakukan dengan berdasarkan bukti kuantitatif dan kualitatif seperti Sanda $^{5}$ dan Putrayasa $^{6}$, tetapi masih bersifat penelitian lepas yang belum dihubungkan dengan kelompok bahasa atau relasi kekerabatan bahasa-bahasa tersebut. Oleh karena itu, penelitian ini merupakan lanjutan untuk membuktikan kembali relasi kekerabatan secara genetis bahasabahasa di Pulau Timor berdasarkan bukti kuantitatif dan bukti kualitatif.

\section{Tujuan dan Manfaat Penelitian}

Tujuan penelitian ini untuk memperoleh fakta bahasa yang akurat tentang relasi genetis bahasa-bahasa di Pulau Timor dengan rincian sebagai berikut.

1) Bertolak dari pengelompokan Capell $^{7}$, Dyen ${ }^{8}$, Blust ${ }^{9}$, Sanda $^{10}$, dan Putrayasa $^{11}$ penelitian ini bertujuan untuk membuktikan kembali tingkat 
keeratan relasi genetis bahasabahasa Timor sebagai satu kelompok tersendiri yang terpisah dari kelompok bahasa lainnya. Keterhubungan secara genetis bahasa-bahasa itu diwujudkan dalam bentuk garis silsilah hubungan genetis yang disusun berdasarkan bukti-bukti kuantitatif dan kualitatif yang mendukungnya.

2) Melakukan rekonstruksi fonologis dan leksikon serta menemukan sistem bunyi yang terjadi pada kelompok bahasa itu. Fungsinya untuk memperkuat temuan keterhubungan secara genetis kelompok bahasa itu yang dikukuhkan dengan ditemukannya protobahasa yang dimiliki bersama secara eksklusif serta rumusan sistem perubahan bunyi yang terjadi pada kelompok bahasa itu.

3) Membuktikan keterhubungan PT yang ditemukan itu dengan PAN yang tercermin pada pantulan fonem-fonem PAN pada protobahasa itu sekaligus membuktikan kembali temuan Capell $^{12}$.

Secara teoretis hasil penelitian ini dapat memberikan sumbangan teori dan khasanah temuan baru dalam bidang linguistik historis komparatif guna memperjelas posisi bahasa-bahasa di Pulau Timor sebagai subrumpun Melayu Polinesia Tengah ${ }^{13}$. Hasil penelitian ini juga mengandung implikasi berdimensi historis kultural. Bahasa Tt merupakan bahasa ibu, baik secara sosial, politik, dan kultural memiliki peranan "baru" dalam kehidupan masyarakat Timor Leste menuju negara mandiri. Sebagai negara yang hidup berdampingan, pemahaman bersama tentang hubungan kesejarahan bahasa, baik bahasa $\mathrm{Tt}$ yang common core-nya sama di Timor Leste dan Timor Indonesia, demikian juga keberadaan beberapa bahasa lokal yang sama di kedua negara itu adalah jembatan kultural penting dalam membina hubungan kedua "masyarakat" itu. Bahasa memang tidak selalu identik dengan bangsa atau etnik. Tetapi, fakta sejarah dan realitas kultural antara masyarakat bahasa $\mathrm{Tt}$ dan $\mathrm{Km}$ serta bahasa lainnya di kedua wilayah itu, jelas memiliki makna dan nilai strategis dalam kehidupan kedua negara dan bangsa itu terutama dalam membina hubungan kerja sama pada masa yang akan datang.

\section{Tinjauan Pustaka}

Pengelompokan berarti penentuan silsilah bahasa demi kejelasan stuktur genetisnya. Rekonstruksi memperjelas hubungan kekerabatan dan ikatan keseasalan bahasa itu sesuai jenjang yang disilsilahkan. Hal itu bermakna, protobahasa sebagai suatu sistem yang diabstraksikan dari wujud bahasa kerabat merupakan pantulan kesejarahan bahwa bahasa-bahasa itu pernah mengalami perkembangan yang sama sebagai bahasa tunggal ${ }^{14}$. 
Rekonstruksi berpijak pada dua hipotesis, yakni hipotesis keterhubungan dan keteraturan ${ }^{15}$. Ciri hipotesis keterhubungan meliputi kemiripan dan kesamaan bentuk-makna cognate set yang bukan pinjaman, kebetulan, atau pun kecenderungan semesta, tetapi dihipotesiskan sebagai warisan dari asal-usul yang sama. Hipotesis keteraturan berwujud perubahan bunyi bersistem, teratur pada bahasa turunan. Sebuah segmen bunyi protobahasa yang terwaris melalui kosakata seasal berubah secara teratur pada bahasa turunan.

Inti penelusuran hubungan genetis bahasa baik untuk tujuan $s u b$ grouping maupun rekonstruksi adalah penemuan bukti kuantitatif dan kualitatif yang meyakinkan terdapat dalam bahasa yang diperbandingkan. Bukti kuantitatif adalah dalam bentuk cognate set yang berkaitan dengan shared retention. Bukti kualitatif berupa shared innovation serta korespondensi fonologis ${ }^{16}$. Penjejakan bukti kuantitatif atau retensi bersama didasarkan atas asumsi bahwa kosakata itu bersifat semesta, inti dan konstan sepanjang masa, intim dengan kehidupan manusia, ada dalam setiap bahasa, usianya setua manusia, dan mampu bertahan $80 \%{ }^{17}, 81 \%^{18}$. Bukti kuantitatif itu dipakai dasar pengelompokan awal suatu bahasa untuk tujuan perolehan persentase kekerabatan dengan leksikostatistik, dan masa pisah setiap bahasa dengan glotokronologis ${ }^{19}$.
Penjejakan bukti kualitatif merupakan upaya penemuan fakta exclusively shared linguistic innovation sebagai warisan protobahasa asal yang hanya terdapat dalam kelompok bahasa itu. Temuan itu dalam bentuk perubahan bunyi yang teratur atau tidak, perubahan bentuk-makna kata $^{20}$. Hukum regulatory sound change yang dipakai dasar, meliputi monophonemization, merger, split, diphonemization, phonemic loss, dll. ${ }^{21}$, dengan tidak mengabaikan Hukum van der Tuuk RGH dan RDL.

\section{Metode Penelitian}

\subsection{Metode Pengelompokan}

Pengelompokan bahasa yang diteliti dilakukan berdasarkan bukti kuantitatif dan kualitatif. Bukti kuantitatif diperoleh melalui data yang terkumpul dengan daftar 200 kosakata dasar $\mathrm{Swadesh}^{22}$. Data itu dianalisis dengan teknik leksikostatistik dengan rumus jumlah pasangan kognat dibagi jumlah gloss yang terisi kali seratus persen. Berdasarkan angka persentase itu dapat diketahui tingkat keeratan hubungan genetis kelompok bahasa itu dan posisinya dengan semua bahasa di sekitarnya serta dengan dasar itu silsilah kekerabatannya dapat disusun.

Pengelompokan itu belum tuntas, untuk itu diperlukan bukti kualitatif yang dapat berfungsi ganda. Pertama, untuk memperkuat silsilah yang telah ditetapkan, jika hasilnya saling mendukung. Kedua, jika 
bertentangan bukti kualitatif berfungsi menganulir hasil sebelumnya ${ }^{23}$. Bukti kualitatif yang diperoleh dengan daftar Holle 1600 kata dianalisis dengan teknik korespondensi terhadap unsurunsur inovasi bersama yang eksklusif. Hasil analisis itu disarikan dalam bentuk klasifikasi (a) bukti penyatu kelompok, dan (b) bukti pemisah kelompok sekaligus penyatu subkelompok. Berdasarkan bukti-bukti itulah tingkat keeratan kelompok bahasa itu ditetapkan dalam bentuk garis silsilah yang difinitif.

\subsection{Metode Rekonstruksi}

Dalam tahap ini dilakukan penemuan protobahasa Timor dan protobahasa di bawahnya. Metode yang digunakan adalah metode rekonstruksi, baik rekonstruksi fonologis maupun leksikal. Cara kerja rekonstruksi protobahasa melalui teknik induktif (bottom-up Reconstruction) ${ }^{24}$. Langkah penetapan protofonem dilakukan dengan cara penetapan protofonem demi protofonem sebagai urutan langkah rekonstruksi fonologi, dilanjutkan dengan rekonstruksi leksikal.

\subsection{Metode Pantulan}

Metode ini digunakan untuk menemukan keterhubungan PAN dengan PT. Proses penemuan keterhubungan kedua protobahasa itu dimaksudkan untuk membuktikan bahwa kelompok bahasa yang diteliti itu diklasifikasikan sebagai kelompok bahasa yang memiliki keseasalan dengan PAN. Cara yang ditempuh dalam proses penemuan keterhubungan kedua protobahasa itu melalui teknik deduktif (Top-down Reconstruction) ${ }^{25}$. Dalam proses ini, keterhubungan antarprotobahasa ditinjau pada dua tingkat yang berbeda, yaitu tingkat yang tertinggi (PAN) dan tingkat yang lebih rendah (PT).

\section{Hasil dan Pembahasan}

\subsection{Pengelompokan Bahasa-bahasa} Timor

\subsubsection{Bukti Kuantitatif}

Bukti di bawah ini diperoleh berdasarkan pendekatan kuantitatif terhadap 13 bahasa Timor. Bukti tersebut disajikan dalam bentuk diagram persentase hasil perhitungan leksikostatistik terhadap kognat yang dikumpulkan menggunakan daftar 200 kata dasar Swadesh ${ }^{26}$. 
Diagram -1

Relasi Genetis Bahasa-bahasa Timor

(Berdasarkan Bukti-bukti Kuantitatif)

\begin{tabular}{|c|c|c|c|c|c|c|c|c|c|c|c|c|}
\hline Tokodede & 41 & & & & & & & & & & & \\
\hline Kemak & 43 & 43 & & & & & & & & & & \\
\hline Tetun & 33 & 33 & 34 & & & & & & & & & \\
\hline Rote & 21 & 26 & 26 & 34 & & & & & & & & \\
\hline Helong & 17 & 25 & 26 & 26 & 26 & & & & & & & \\
\hline Dawan & 17 & 17 & 17 & 30 & 30 & 24 & & & & & & \\
\hline Bunak & 08 & 07 & 08 & 09 & 04 & 04 & 02 & & & & & \\
\hline Makasai & 04 & 02 & 02 & 05 & 03 & 03 & 03 & 04 & & & & \\
\hline Fataluku & 01 & 01 & 02 & 02 & 03 & 02 & 03 & 02 & 15 & & & \\
\hline Mauta & 02 & 01 & 00 & 02 & 01 & 02 & 02 & 02 & 02 & 03 & & \\
\hline Kolana & 03 & 01 & 01 & 01 & 00 & 01 & 02 & 01 & 02 & 02 & 01 & \\
\hline \multirow[t]{2}{*}{ Klong } & 01 & 01 & 01 & 01 & 01 & 01 & 00 & 02 & 02 & 03 & 02 & 05 \\
\hline & 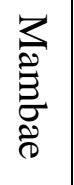 & $\begin{array}{l}1 \\
0 \\
\frac{1}{0} \\
0 \\
0 \\
2\end{array}$ & 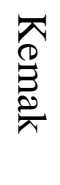 & $\stackrel{\overrightarrow{\mathbb{Q}}}{\Xi}$ & $\underset{0}{\stackrel{0}{0}}$ & $\frac{\mathbb{T}}{\stackrel{D}{D}}$ & 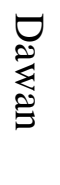 & 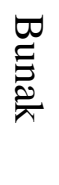 & 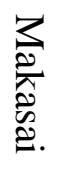 & 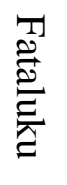 & 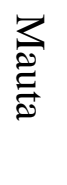 & 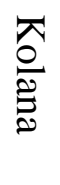 \\
\hline
\end{tabular}

Diagram 1 di atas menunjukkan bahwa kelompok bahasa Timor terdiri atas tiga subkelompok, yaitu subkelompok TKM, subkelompok DRT, dan subkelompok Hl. Tingkat keeratan relasi genetis masing-masing subkelompok dengan urutan sebagai berikut. Subkelompok pertama yakni subkelompok TKM dengan angka persentase antara $41 \%$ sampai $43 \%$. Subkelompok kedua adalah subkelompok DTR dengan angka persentase antara 30\% sampai $34 \%$. Subkelompok ketiga yakni $\mathrm{Hl}$ yang hanya mencapai rerata $25 \%$. Angka persentase itu mengindikasikan ada sebuah bahasa sebagai subkelompok yang berbeda. Dengan demikian kelompok bahasa Timor dimungkinkan terdiri atas tiga subkelompok yang membentuknya.

\subsubsection{Bukti Kualitatif}

\subsubsection{Kelompok Bahasa Timor}

\section{a. Bukti Penyatu Kelompok Bahasa Timor}

Kelompok bahasa sekerabat di Pulau Timor yang terdiri atas sepuluh bahasa memiliki inovasi bersama secara eksklusif, baik fonologis maupun leksikal. Inovasi bersama yang eksklusif itu dirinci sebagai berikut. 


\section{1) Inovasi Fonologis}

Ada beberapa perubahan bersama yang teratur dan bersistem terjadi pada fonologi PT sebagai akibat perjalanan panjang fonologi
PAN. Inovasi fonologis bersama yang terjadi dalam bentuk apokope, sinkope, penunggalan bunyi, dan pengedepanan bunyi sentral PAN * $\partial$ seperti tampak berikut ini.

\section{(1) Apokope}

$\begin{array}{lll}\text { PAN } & \text { PT } & \\ \text { *anak } & \text { *ana } & \text { 'anak' } \\ \text { *tasik } & \text { *tasi } & \text { 'laut' } \\ \text { *minak } & \text { *mina } & \text { 'minyak, berlemak' }\end{array}$

(2) Sinkope

$\begin{array}{lll}\text { PAN } & \text { PT } & \\ \text { *buwah } & \text { *bua } & \text { 'buah' } \\ \text { *tuwak } & \text { *tua } & \text { 'tuak' } \\ \text { *duwah } & \text { *rua } & \text { 'dua' }\end{array}$

(3) Penunggalan bunyi

$\begin{array}{lll}\text { PAN } & \text { PT } & \\ \text { *mataj } & * \text { mata } & \text { 'mata, } \\ *[\mathrm{t}] \text { oluy } & *_{\text {telo }} & \text { 'telur' } \\ \text { *ikuy } & * \text { iku } & \text { 'ekor' }\end{array}$

(4) Pengedepanan bunyi sentral PAN $* \partial$

\begin{tabular}{|c|c|c|}
\hline $\mathrm{PAN} * \partial$ & $\mathrm{PT} * \mathrm{e}$ & \\
\hline$*_{\mathrm{t}} \partial \mathrm{bu}$ & $*_{\text {tehu }}$ & 'tebu' \\
\hline$*[\mathrm{t}] \partial \mathrm{luy}$ & *telo & 'telt \\
\hline$*_{\mathrm{t} \partial \mathrm{lu}}$ & $*$ telu & 'tiga' \\
\hline
\end{tabular}

\section{2) Inovasi Leksikal}

Selain inovasi fonologis, ditemukan juga inovasi leksikal sebagai bukti kualitatif penyatu kelompok bahasa Timor. Beberapa etimon yang ditemukan itu merupakan kosakata yang dimiliki bersama secara eksklusif pada kelompok itu dan tidak ditemukan pasangan kognatnya pada kelompok bahasa lain di sekitarnya, seperti na?e 'naik', lete 'jembatan', DeRo 'jeruk', tasu 'kuali', liRa 'sayap' dll.

\section{b. Bukti Pemisah Kelompok Bahasa} Timor

Berdasarkan bukti kualitatif, kelompok bahasa Timor terdiri atas tiga subkelompok, yakni subkelompok Tk-Km-Mb (TKM), Dw-Tt-Rt (DTR), dan subkelompok $\mathrm{Hl}$ yang hanya terdiri 
atas satu bahasa. Inovasi bersama baik fonologis maupun leksikal yang dimiliki itu merupakan bukti pemisah kelompok Timor sekaligus juga sebagai bukti penyatu subkelompok masing-masing. Inovasi eksklusif bersama itu dirinci sebagai berikut.

\section{(1) $\mathbf{P T} * \mathbf{b}$}

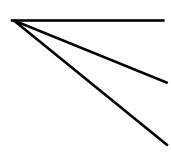

*h (PTKM)

*f (PDTR)

b (HI)

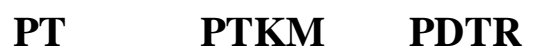

$\begin{array}{lll}* \text { bini } & \text { *hini } & * \text { fini } \\ \text { *batu } & * \text { hatu } & * \text { fatu(k) } \\ \text { *bula(n) } & * \text { hula } & * \text { fula(n) } \\ \text { *bahi } & * \text { hahi } & * \text { fa(h)fi } \\ \text { *base } & * \text { has(a) } & * \text { fase }\end{array}$

(2) Apokope pada PTKM

$\begin{array}{ll}\text { PTKM } & \text { PDTR } \\ *_{\text {tun }} & *_{\text {tunu }} \\ *_{\text {sim }} & *_{\text {simo }} \\ *_{\text {ut }} & *_{\text {uta }}\end{array}$

(3) Metatesis pada PDTR

$\begin{array}{ll}\text { PTKM } & \text { PDTR } \\ *_{\text {taku }} & *_{\text {tauk }} \\ *_{\text {ma }(r) \mathrm{u}} & *_{\text {maus }} \\ *_{\mathrm{a}(\mathrm{u})} & *_{(\mathrm{h}) \mathrm{au}}\end{array}$

(4) Paragoge pada Hl

$\begin{array}{ll}\text { PTKM } & \text { PDTR } \\ *_{\text {tun }} & *_{\text {tunu }} \\ *_{\text {sim }} & *_{\text {simo }} \\ *_{\text {ut }} & *_{\text {uta }}\end{array}$

(5) Metatesis pada $\mathrm{HI}$

$\begin{array}{llll}\text { PTKM } & \text { PDTR } & \text { HI } & \\ \text { *lila(r) } & \text { *li(r)da } & \text { dila } & \text { 'sayap' } \\ \text { *hatu } & \text { *fatu } & \text { baut } & \text { 'jinak' } \\ \text { *has(a) } & \text { *fase } & \text { Baes } & \text { 'cuci,bersihkan' }\end{array}$

HI

Bini 'benih'

Baut 'batu'

Bulan 'bulan'

Bahi 'babi'

Baes 'cuci,bersihkan'
HI

Tunun 'membakar'

Simun 'menerima'

Utan 'sayur'
HI

Tauk 'takut' moa' 'jinak' $\mathrm{Au} \quad$ 'saya'
HI

Tunun 'membakar'

Simun 'menerima'

Utan 'sayur'

\section{1) Inovasi Fonologis}

Beberapa inovasi

fonologis bersama berikut ini dapat menjadi bukti pemisah kelompok bahasa Timor. Bukti fonologis di bawah ini memberi gambaran keteraturan perubahan fonem yang terjadi pada masing-masing subkelompok yang membentuknya. 


\section{2) Inovasi Leksikal}

Ada sejumlah inovasi leksikal yang dimiliki masingmasing subkelompok sebagai bukti pemisah kelompok bahasa Timor. Bukti pemisah kelompok dalam

$\begin{array}{llll}\text { PTKM } & \text { PDTR } & \text { Hl } & \\ \text { *mahu } & \text { *boho } & \text { kode } & \text { 'batuk' } \\ \text { *kala } & \text { *sos(a) } & \text { sosan } & \text { 'membeli' } \\ \text { *barau(s) } & \text { *na(b)ok } & \text { nako } & \text { 'mencuri' } \\ \text { *tata } & \text { *bei } & \text { upung suas } & \text { 'moyang' } \\ \text { *bian } & \text { *p(b)ika } & \text { pingas } & \text { 'piring' } \\ \text { *moda } & \text { *olo } & \text { holon } & \text { 'telan' } \\ \text { *(h)ure } & \text { *fue } & \text { bula } & \text { 'kacang' } \\ \text { *lako } & \text { *kal(a) } & \text { kala } & \text { 'kalah' } \\ \text { *pesu } & \text { *sui } & \text { nisu' } & \text { 'kentut' } \\ \text { *busa } & \text { *meo } & \text { luis } & \text { 'kucing' } \\ \text { *mori } & \text { *maris } & \text { nuli' } & \text { 'hidup' }\end{array}$

5.1.2.2 Subkelompok TKM

\section{a. Bukti Penyatu Subkelompok TKM}

\section{1) Inovasi Fonologis TKM}

Inovasi fonologis penyatu subkelompok TKM tampak jelas jika dikaitkan dengan kelompok bahasa Timor. bentuk inovasi leksikal itu sekaligus juga sebagai bukti penyatu subkelompok masingmasing, karena hanya dimiliki oleh subkelompok tertentu dan tidak terdapat pada subkelompok lainnya.

\section{Terdapat perubahan yang eksklusif dalam perjalanan sejarah dari PT menjadi subkelompok TKM. Inovasi fonologis tersebut berupa split PT *b menjadi $*$ b dan *h pada PTKM.}

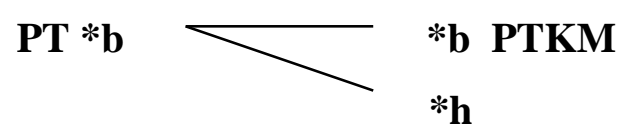

\begin{tabular}{|l|l|l|}
\hline PT & PTKM & \\
\hline *besu & *beso & 'kenyang' \\
\hline *buti & *buti & 'putih' \\
\hline *bua & *bua & 'pinang' \\
\hline *batu & *hat(u) & 'batu' \\
\hline *bini & *hin(i) & 'benih' \\
\hline *bulan & *hula(i,h) & 'bulan' \\
\hline
\end{tabular}

\section{2) Inovasi Leksikal TKM}

Bukti inovasi leksikal tersebut seperti tampak pada beberapa contoh berikut ini. 


$\begin{array}{lll}\text { PTKM } & \text { *kalsa } & \text { 'celana' } \\ & \text { *dosi } & \text { 'kue' } \\ & \text { *busa } & \text { 'kucing' } \\ & \text { *dai } & \text { 'jala' } \\ & \text { *tugu } & \text { 'bertanya' } \\ & \text { *fiar } & \text { 'agama', dst. }\end{array}$

\section{b. Bukti Pemisah Subkelompok TKM}

1) Inovasi Fonologis Mambae

(1) Apokope

(2) Metatesis

(3) Merger PTK *e

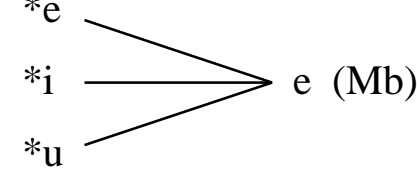

(4) Merger PTK

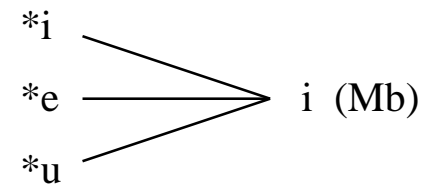

(5) $\mathrm{PTK} * \mathrm{p}>\mathrm{f}(\mathrm{Mb})$

2) Inovasi Fonologis Tokodede-Kemak

Split PTK *i<smiles>CCCCCCC</smiles>

3) Inovasi Leksikal

PTK

*agora

*bana(sa)

*bobo

$*$ dae

*dai

dst
Mb

enene 'sekarang' ronu 'panas' ko'o 'bersembunyi' tar 'membacok'

er suru 'bubu' (alat tangkap ikan)

\subsubsection{Subkelompok DTR}

a. Bukti Penyatu Subkelompok DTR

1) Inovasi Fonologis DTR

$\mathbf{P T} * \mathbf{b}$

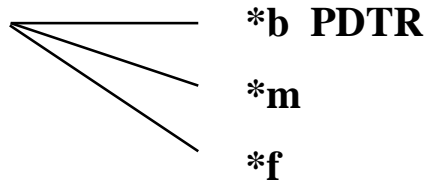


2) Inovasi Leksikal DTR

\begin{tabular}{|c|c|c|}
\hline \multirow[t]{8}{*}{ PDTR } & $*$ bei & 'nenek moyang' \\
\hline & $*$ lili & 'ketiak' \\
\hline & *lafo & 'tikus' \\
\hline & $*_{\mathrm{fe}}$ & 'memberikan' \\
\hline & $*$ fui $(\mathrm{k})$ & 'liar' \\
\hline & $*_{\text {fiti }}$ & 'betis' \\
\hline & *masu & 'menguap' \\
\hline & $*$ tao & 'mengisi', dst. \\
\hline
\end{tabular}

b. Bukti Pemisah Subkelompok DTR

1) Inovasi Fonologis Subkelompok TR - Dw

(1) Merger PTR *1 $* \mathrm{R}$

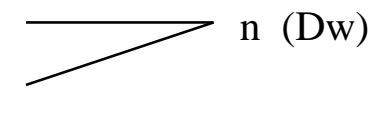

(2) Split PTR *a

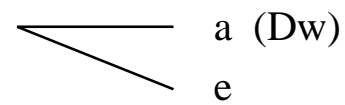

(3) $\mathrm{PTR} * \mathrm{~d}>1(\mathrm{Dw})$

(4) Metatesis

2) Inovasi Leksikal Dw - PTR

\begin{tabular}{|l|l|l|}
\hline Dw & PTR & \\
\hline nakfe'e & *te(i) & 'berak' \\
\hline Sulat & *buku & 'buku' \\
\hline Ite & *lati(k) & 'cacing' \\
\hline ume hana & *dapu(r) & 'dapur' \\
\hline In & *sia & 'dia', dst. \\
\hline
\end{tabular}

\subsubsection{Subkelompok Helong (HI)}

\section{Bukti Penyatu Subkelompok HI}

1) Inovasi Fonologis $\mathrm{HI}$

(1) Pantulan fonem PT *b > b (Hl)

(2) Metatesis

(3) Split PT *e<smiles>CCCC</smiles>

\section{2) Inovasi Leksikal HI}

Hl

$$
\begin{aligned}
& \text { moki } \\
& \text { klaputa } \\
& \text { hela' } \\
& \text { ngot } \\
& \text { aleng } \\
& \text { nopen }
\end{aligned}
$$

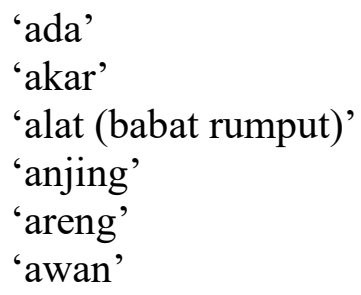




$\begin{array}{ll}\text { banan } & \text { 'bagus' } \\ \text { blipa } & \text { 'balian, dukun' } \\ \text { kluni } & \text { 'bantal' } \\ \text { heting } & \text { 'betina' } \\ \text { dake } & \text { 'bekerja' } \\ \text { bi } & \text { 'belum' } \\ \text { bunga } & \text { 'benang' } \\ \text { dst. } & \end{array}$

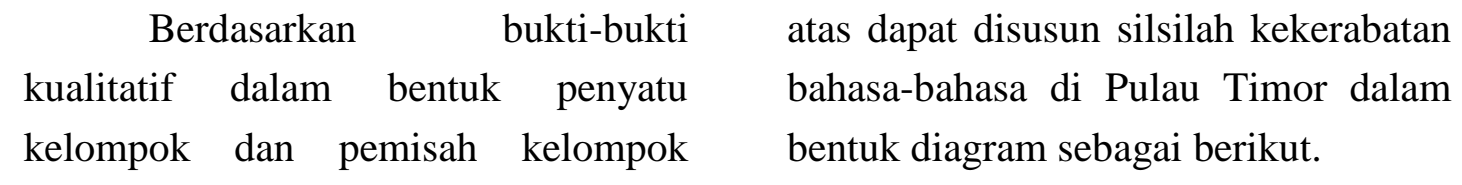

sekaligus penyatu sub-subkelompok di

Diagram -2

Garis Silsilah Relasi Genetis Bahasa-Bahasa Timor

(Berdasarkan bukti-bukti kualitatif)

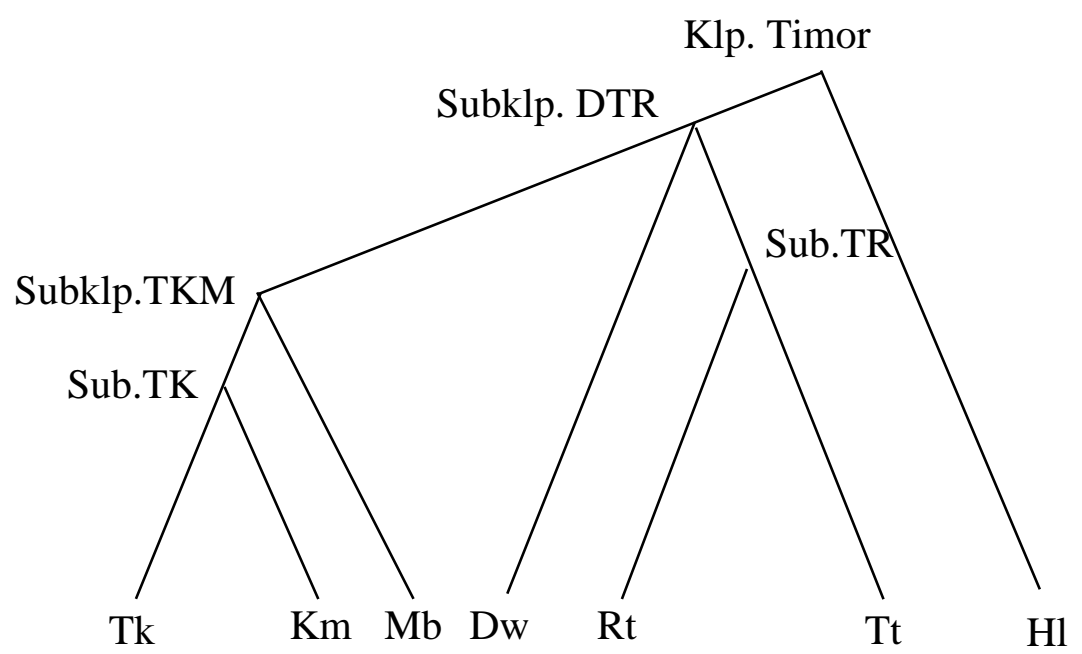

(Subklp).

Diagram $\quad-2$ di atas hanya beranggotakan sebuah bahasa. menunjukkan bahwa tujuh bahasa yang Bukti kualitatif ini lebih rinci sekaligus diteliti merupakan satu kelompok yang mengukuhkan bukti kuantitatif. Dengan sama sebagai kelompok bahasa Timor. demikian, silsilah di atas dapat Kelompok Timor itu terdiri atas tiga ditetapkan sebagai garis silsilah relasi subkelompok masing-masing subkelompok TKM yang beranggotakan subkelompok TK dan $\mathrm{Mb}$, DTR dengan Dw dan RT di bawahnya, dan subkelompok $\mathrm{Hl}$ yang genetis bahasa-bahasa Timor.

5.2 Rekonstruksi Protobahasa Timor

Setelah garis silsilah hubungan genetis kelompok bahasa Timor ditetapkan, maka rekonstruksi 
protobahasanya dapat dilakukan. protofonem vokal dan konsonan seperti Langkah yang ditempuh adalah tersusun dalam peta fonem di bawah penemuan fonem demi fonem semua ini. bahasa yang diteliti, dilanjutkan ke masing-masing sub-subkelompok di atasnya sampai pada kelompok Timor dengan penetapan akhir pada penemuan etimon PT (bottom-up reconstuction). Melalui rekonstruksi fonologis ditemukan sejumlah

\section{1) Rekonstruksi Fonologis}

Protofonem vokal yang ditemukan dalam PT berjumlah lima buah seperti tampak pada peta fonem berikut ini.

\begin{tabular}{|c|c|c|c|}
\hline & Depan & Tengah & Akhir \\
\hline Tinggi & $*_{\mathrm{i}}$ & & $*_{\mathrm{u}}$ \\
\hline Sedang & $*_{\mathrm{e}}$ & & $*_{\mathrm{O}}$ \\
\hline Rendah & \multicolumn{3}{|c|}{$* a$} \\
\hline $\begin{array}{l}\text { Di s } \\
\text { ditemukan } \\
\text { protofones }\end{array}$ & $\begin{array}{l}\text { protofon } \\
\text { a empa } \\
\text { isonan } \mathrm{F}\end{array}$ & $\begin{array}{l}\text { vokal } \\
\text { belas } \\
\text { yang }\end{array}$ & $\begin{array}{l}\text { disusun dalam peta fonem konsonan } \\
\text { sebagai berikut. }\end{array}$ \\
\hline
\end{tabular}

$\begin{array}{lllllll}\text { Hambat TB } & \begin{array}{l}\text { Labial } \\ *_{\mathrm{p}}\end{array} & \begin{array}{l}\text { Dental } \\ *_{\mathrm{t}}\end{array} & \text { Retrofleks } & \begin{array}{l}\text { Velar } \\ *_{\mathrm{k}}\end{array} & \text { Uvular } & \begin{array}{l}\text { Glotal } \\ * ?\end{array} \\ & \mathbf{B} & *_{\mathrm{b}} & & *_{\mathrm{D}} & *_{\mathrm{G}} & \\ \text { Nasal } & *_{\mathrm{m}} & *_{\mathrm{n}} & & & \\ \text { Lateral } & & *_{\mathrm{l}} & & & \\ \text { Getar } & & & & * \mathrm{R} \\ \text { Frikatif } & *_{\mathrm{f}} & *_{\mathrm{s}} & & & \end{array}$

Semi Vokal

3) Rekonstruksi Leksikal

Upaya akhir penelusuran protobahasa (PT) melalui rekonstruksi adalah penemuan etimon PT. Melalui rekonstruksi leksikal ditemukan \pm 80 kosakata seasal PT yang disusun dalam bentuk alpabetis. 


\subsection{Pantulan PAN dalam PT}

Dalam penelusuran terhadap perkembangan sejarah protofonem melalui kaji banding antara PAN dengan PT sampai pada bahasa-bahasa Timor sekarang, terdapat sejumlah fonem yang mengalami perubahan teratur sehingga mudah ditelusuri (seperti pantulan langsung) dan ada pula yang kacau sehingga sulit ditelusuri. Berikut ini disajikan beberapa perubahan fonem yang terjadi (selain fonem PT sebagai pantulan langsung dari PAN).

(1) Pengedepanan fonem PAN * $\partial$ menjadi PT *e secara teratur.

(2) Split fonem PAN $*$ d menjadi PT $* \mathrm{D}$ dan $* \mathrm{R}$ dengan tidak teratur.

(3) Split fonem PAN *k menjadi PT *k/ \#_(teratur), *?/ V_V, * $*^{*}$ / \# (tak teratur)

(4) Penunggalan fonem PAN *aj, *aw, *uy secara tidak teratur.

(5) Apokope fonem PAN *r, *R, *v, *q, *y, dan *j dengan tidak teratur.

(6) Sinkope fonem PAN $*_{\mathrm{w}}, *_{\mathrm{v}}$, *j, dengan tidak teratur.

Berdasarkan pantulan PAN pada PT baik secara langsung maupun melalui berbagai proses yang teratur dan tidak teratur, maka terbukti kelompok bahasa Timor sebagai bahasa AN.

\section{Simpulan dan Saran}

1) Bahasa-bahasa Tk, Km, Mb, Dw, $\mathrm{Rt}, \mathrm{Tt}$, dan $\mathrm{Hl}$ yang hidup di wilayah Timor Leste dan wilayah Indonesia terbukti memiliki hubungan genetis yang erat sebagai kelompok bahasa Timor. Kelompok bahasa Timor terdiri atas tiga subkelompok yang membentuknya dengan struktur pola dwipilah secara bertahap dari subkelompok kecil yang paling bawah sampai pada kelompok Timor. Sub-subkelompok tersebut meliputi subkelompok TKM yang terdiri atas TK dan $\mathrm{Mb}$, subkelompok DRT yang terdiri atas Dw dan RT, dan subkelompok $\mathrm{Hl}$ yang hanya beranggotakan sebuah bahasa.

2) Keakuratan pengelompokan bahasa Timor dibuktikan dengan ditemukannya PT dalam bentuk protofonem (melalui rekonstruksi fonologis) dan dalam bentuk sejumlah protokata (melalui rekonstruksi leksikon). Protofonem (PT) terdiri atas fonem vokal * $\mathrm{i}$, *u, dan *a yang dapat berdistribusi lengkap, vokal *e dan *o yang tidak ditemukan pada posisi awal kata, fonem konsonan $* \mathrm{p}, * \mathrm{~b}, * \mathrm{D},{ }^{*} \mathrm{G}, * \mathrm{f}$ yang hanya dapat berdistribusi pada awal kata, konsonan *k, *m, dan *1 pada posisi awal dan tengah kata, konsonan $*$ ? pada posisi tengah dan akhir kata, serta konsonan *t, *n, 
$* \mathrm{R}, * \mathrm{~s}$, dan $* \mathrm{~h}$ dapat berdistribusi lengkap.

3) Protobahasa Timor (PT) yang telah ditemukan merupakan pantulan PAN baik melalui proses secara langsung maupun melalui proses perubahan bunyi secara teratur atau tidak teratur, membuktikan bahwa kelompok bahasa Timor dapat diklasifikasikan sebagai bahasa AN sekaligus menolak klasifikasi Capell $^{27}$.
Hasil penelitian yang mengungkap fakta sejarah dan kultur masyarakat bahasa Pulau Timor yang terbagi menjadi dua negara (Indonesia dan Timor Leste) telah terbukti berasal dari genetis yang sama. Diharapkan hasil penelitian ini dapat dipakai sebagai media membina hubungan bilateral kedua negara itu, selain dapat memberi motivasi bagi penelitian yang lebih luas dan mendalam terhadap hubungan historis dan kultur masyarakat bahasa di wilayah tersebut.

\section{DAFTAR PUSTAKA}

${ }^{1}$ Capell, A. 1945. "Peoples and Languages of Timor” dalam Occania No. 15

${ }^{2}$ Blust, Robert A. 1981. "Variation and Retension Rate among Austronesia Language" Makalah Seminar Linguistik Austronesia III. Denpasar Bali.

${ }^{3}$ Dyen, Isodore. 1965. A Lexicastatistical Classification of the Melayu-Polinesian Language . Baltimore: the Waverly Press.

${ }^{4}$ Blust, Robert A. 1981. "Variation and Retension Rate among Austronesia Language” Makalah Seminar Linguistik Austronesia III. Denpasar Bali.

${ }^{5}$ Sanda, Fransiskus. 1998. "Rekonstruksi Protobahasa Mambai-Tokodede-Kemak (PMTK) di Timor Timur”. Tesis untuk Program Pasca Sarjana Universitas Udayana, Denpasar.

${ }^{6}$ Putrayasa, I Gusti Ngurah. 1998. "Hubungan Kekerabatan Bahasa Tetun-RoteDawan: Kajian Linguistik Historis Komparatif". Tesis untuk Program Pascasarjana Universitas Udayana, Denpasar.

${ }^{7}$ Capell, A. 1945. “Peoples and Languages of Timor” dalam Occania No. 15

${ }^{8}$ Dyen, Isodore. 1965. A Lexicastatistical Classification of the Melayu-Polinesian Language . Baltimore : the Waverly Press.

${ }^{9}$ Blust, Robert A., op.cit. ${ }^{4}$ Blust, Robert A. 1981. "Variation and Retension Rate among Austronesia Language" Makalah Seminar Linguistik Austronesia III. Denpasar Bali. 
${ }^{10}$ Sanda, Fransiskus. 1998. "Rekonstruksi Protobahasa Mambai-Tokodede-Kemak (PMTK) di Timor Timur". Tesis untuk Program Pasca Sarjana Universitas Udayana, Denpasar.

${ }^{11}$ Putrayasa, I Gusti Ngurah. 1998. "Hubungan Kekerabatan Bahasa Tetun-RoteDawan: Kajian Linguistik Historis Komparatif". Tesis untuk Program Pascasarjana Universitas Udayana, Denpasar.

${ }^{12}$ Capell, A. 1945. "Peoples and Languages of Timor" dalam Occania No. 15

${ }^{13}$ Blust, Robert A., op.cit. ${ }^{4}$ Blust, Robert A. 1981. "Variation and Retension Rate among Austronesia Language" Makalah Seminar Linguistik Austronesia III. Denpasar Bali.

${ }^{14}$ Antilla, Raimo. 1972. An Itroduction to Historical and Comparative Linguistics. New York: Macmillan.

${ }^{15}$ Hock, Hans H. 1988. Principles of Historical Linguistics. Berlin: Mouton de Gruyter.

${ }^{16}$ Crowley, Terry. 1983. An Introduction to Historical Linguistics. Port Moresby: University of Papua New Guenia Press.

${ }^{17}$ Crowley, Terry. 1983. An Introduction to Historical Linguistics. Port Moresby: University of Papua New Guenia Press.

${ }^{18}$ Hockett, Charles F. 1963. A Course in Modern Linguistic. New York: The Macmillan Company.

${ }^{19}$ Dyen, Isodore. 1978. “ The Positions of the Languages of Eastern Indonesia”. Proccedings SICAL, Fascicle 1:235--254 Pl C.61.

${ }^{20}$ Penzl, Herbert. 1969. "The Evidence for Phonemic Change" dalam Lass (ed.) Lass, Roger. (ed.).1969. Approach to English Historical Linguistics An Anthology. New York: Holt.

${ }^{21}$ Blust, Robert A., op.cit. ${ }^{4}$ Blust, Robert A. 1981. "Variation and Retension Rate among Austronesia Language" Makalah Seminar Linguistik Austronesia III. Denpasar Bali.

${ }^{22}$ Swadesh, Morris. 1972. The Originand Diversification of Language. London: Routledge \& Kegen Paul.

${ }^{23}$ Dempwolff, Otto. 1938. Vergleichende Lautlehre des Austronesiaschen Wortschatzes III: Austronesiaschen Worterverzeichnis. Hamburg: Friederrichen, de Gruyter. 
${ }^{24}$ Dempwolff, Otto. 1938. Vergleichende Lautlehre des Austronesiaschen Wortschatzes III: Austronesiaschen Worterverzeichnis. Hamburg: Friederrichen, de Gruyter.

${ }^{25}$ Blust, Robert A. 1981. "Variation and Retension Rate among Austronesia Language" Makalah Seminar Linguistik Austronesia III. Denpasar Bali.

${ }^{26}$ Swadesh, Morris. 1972. The Originand Diversification of Language. London: Routledge \& Kegen Paul.

${ }^{27}$ Capell, A. 1945. "Peoples and Languages of Timor" dalam Occania No. 15 
18| Mabasan, Vol. 6 No. 2, Juli-Desember 2012 